Cinémas

Revue d'études cinématographiques

Journal of Film Studies

\title{
[Présentation]
}

\section{André Gaudreault}

Volume 24, numéro 1, automne 2013

URI : https://id.erudit.org/iderudit/1023113ar

DOI : https://doi.org/10.7202/1023113ar

Aller au sommaire du numéro

Éditeur(s)

Cinémas

ISSN

1181-6945 (imprimé)

1705-6500 (numérique)

Découvrir la revue

Citer ce document

Gaudreault, A. (2013). [Présentation]. Cinémas, 24(1), 133-133.

https://doi.org/10.7202/1023113ar d'utilisation que vous pouvez consulter en ligne.

https://apropos.erudit.org/fr/usagers/politique-dutilisation/ 
Dans le cadre des célébrations entourant le cinquantième anniversaire de fondation de la Cinémathèque québécoise, la revue Cinémas rend hommage à sa façon à cette institution patrimoniale en offrant à ses lecteurs et lectrices un dossier spécial dans chacune de ses deux livraisons de l'année 2013, qui mettront en valeur l'important et essentiel travail de conservation et de diffusion du patrimoine cinématographique et audiovisuel mondial effectué par la Cinémathèque québécoise.

Le dossier spécial qui suit, réalisé avec la précieuse collaboration de Marco de Blois, programmateur et conservateur (cinéma d'animation) à la Cinémathèque québécoise, met en relief la place significative occupée par l'animation au sein de l'institution québécoise. Cinémas vous invite à en apprendre davantage sur les collections d'animation de la Cinémathèque, un trésor qui témoigne de l'engagement de cette institution en ce qui a trait à la pratique de l'animation à Montréal, au Québec, au Canada ainsi que sur le plan international, et ce, depuis maintenant cinquante ans.

André Gaudreault, directeur 